\title{
Umbilical cord clamping and preterm infants: a randomised trial
}

\author{
S Kinmond, T C Aitchison, B M Holland, J G Jones, T L Turner, C A J Wardrop
}

Abstract

Objective-To investigate the clinical effects of regulating umbilical cord clamping in preterm infants.

Design-A prospective randomised study.

Setting-The Queen Mother's Hospital, Glasgow.

Subjects-36 vaginally delivered infants over 27 and under 33 weeks' gestation.

Intervention-Holding the infant $20 \mathrm{~cm}$ below the introitus for 30 seconds before clamping the umbilical cord ("regulated" group, 17 patients), or conventional management ("random" group, 19 patients).

Main outcome measures-Initial packed cell volume, peak serum bilirubin concentrations, red cell transfusion requirements, and respiratory impairment (assessed by ventilatory requirements, arterial-alveolar oxygen tension ratio over the first day in ventilated infants, and duration of dependence on supplemental oxygen).

Results-There were statistically significant differences between the two groups in mean initial packed cell volume (regulated group 0.564 , random group 0.509) and median red cell transfusion requirements (regulated group zero, random group $23 \mathrm{~m} / \mathrm{kg}$ ). 13 infants from each group underwent mechanical ventilation and showed significant differences in mean minimum arterial-alveolar oxygen tension ratio on the first day (regulated group 0.42 , random group 0.22 ) and in median duration of dependence on supplemental oxygen (regulated group three days, random group 10 days). Differences in final outcome measures such as duration of supplemental oxygen dependence and red cell transfusion requirements were mediated primarily through arterial-alveolar oxygen tension ratio and also packed cell volume.

Conclusions-This intervention at preterm

Queen Mother's Hospital, Department of Child

Health, University of Glasgow

S Kinmond, senior registrar

B M Holland, consultant

paediatrician

T L Turner, Leonard Gow

lecturer

Department of Statistics,

University of Glasgow

T C Aitchison, lecturer

Department of

Biochemistry, University of

Wales, Cardiff

J G Jones, senior lecturer

\section{Department of}

Haematology, University

of Wales College of

Medicine, Cardiff

C A J Wardrop, senior lecturer

Correspondence to:

Dr S Kinmond, Special Care

Baby Unit, Ayrshire Central

Hospital, Irvine KA12 8SS.

$B M F$ 1993;306:172-5 (or of the head at assisted breech delivery) to cord clamping. Infants with haemolytic disease or with major congenital malformations were excluded from analysis.

Seventeen infants were enrolled in the regulated group and 19 in the random group. Table I shows their characteristics. All but one (regulated group) were above the 10 th centile for weight. There was a chance excess of boys in the regulated group. All infants in the regulated group had their cords clamped between 25 and 35 seconds after delivery; positioning $20 \mathrm{~cm}$ below the introitus was possible in all but two cases. The median interval to cord clamping in the random group was 10 seconds, and clamping was within 20 seconds in all but one case ( 25 seconds). Only one infant in the random group was held below the introitus.

TABLE I-Characteristics of regulated and random groups of infants

\begin{tabular}{lcc}
\hline & Regulated $(\mathrm{n}=17)$ & Random $(\mathrm{n}=19)$ \\
\hline $\begin{array}{l}\text { Median gestational age (weeks) } \\
\text { (range) }\end{array}$ & $30(27-32)$ & $30(27-32)$ \\
Median birth weight (g) (range) & $1500(1010-2330)$ & $1600(1070-2410)$ \\
Male:female & $13: 4$ & $7: 12$ \\
Instrumental delivery & 7 & 2 \\
\hline
\end{tabular}

Outcome measures recorded included Apgar scores, initial packed cell volume, peak serum bilirubin concentrations recorded, red cell transfusions required and respiratory impairment assessed by ventilatory requirements, arterial-alveolar oxygen tension ratio over the first day in ventilated infants, and duration of dependence on supplemental oxygen. Packed cell volume was measured in the first arterial or venous blood sample obtained, usually when establishing arterial access. It was not logistically feasible to standardise the sampling time; in 23 of the 36 cases this was between 45 and 120 minutes after birth. The distribution of sampling times in both groups was comparable. The arterial-alveolar oxygen tension ratio was calculated with each arterial blood gas analysis over the first day.

Unit policy was consistent over the study period. Infants under 30 weeks' gestation were electively ventilated from birth. The study was terminated when exogenous surfactant was introduced because this influenced our respiratory outcome measures.

Statistical methods-Sample sizes of 15 to 20 in each group were targeted to detect a reduction in median number of transfusions from two to one per infant and an increase in the mean of median arterial-alveolar oxygen tension ratios on day 1 from 0.3 to 0.5 with a power of $80 \%$ and a significance level of $5 \%$. Where normality for each group separately was found to be appropriate by using probability plots a two sample $t$ test was used to compare the mean values of each variable of interest between the regulated and random groups. In cases where the assumption of equal variances was found to be unreasonable an approximate version of the two sample $t$ test was adopted. ${ }^{10}$ When normality for either group was not reasonable the corresponding test used was the Mann-Whitney, although this assumed that the shapes of the two underlying distributions (for regulated and random) were identical but possibly shifted in terms of the median. To investigate relations between sets of 
possible explanatory factors and each outcome variable a stepwise multiple linear regression analysis was used." At each step variables were available for inclusion or exclusion as appropriate. Checks on the final model included residual plots, probability plots of residuals, and formal tests of equality of slopes for the two groups where appropriate.

\section{Results}

There were no significant differences between the groups in Apgar scores, admission temperature, or blood pressure stability on the first day. Two infants in the regulated group and three in the random group did not develop the respiratory distress syndrome; one of these (random group) had been ventilated electively. Thirteen infants in each group were ventilated; table II shows their characteristics. Table III shows overall results, and table IV results for the 26 ventilated infants. Mean and standard deviation of normally distributed results are shown; otherwise median and range are given.

Seven of 13 ventilated infants in the random group required multiple red cell transfusions compared with one of 13 in the regulated group $(p=0.03$; Fisher's exact test). For those not requiring red cell transfusion there was no difference in packed cell volume between the groups at 1 month. Ten of 13 ventilated infants in the random group received fractions of inspired oxygen of 0.6 or more compared with two of 13 in the regulated group $\left(p<0.01 ; \chi^{2}\right.$ test). Median and minimum arterial-alveolar oxygen tension ratios for ventilated infants on the first day were significantly lower in the random group. The difference in duration of ventilation was not significant but median duration of

TABLE II-Characteristics of ventilated infants

\begin{tabular}{lcc}
\hline & Regulated $(\mathrm{n}=13)$ & Random $(\mathrm{n}=13)$ \\
\hline $\begin{array}{l}\text { Median gestational age (weeks) } \\
\text { (range) }\end{array}$ & $30(27-31)$ & $30(27-32)$ \\
Median birth weight (g) (range) & $1500(1010-2020)$ & $1600(1070-2410)$ \\
Male:female & $10: 3$ & $6: 7$ \\
Instrumental delivery & 4 & 1 \\
\hline
\end{tabular}

TABLE III-Outcome in the two study groups

\begin{tabular}{|c|c|c|c|c|}
\hline & $\begin{array}{c}\text { Regulated } \\
(\mathrm{n}=17)\end{array}$ & $\begin{array}{c}\text { Random } \\
(n=19)\end{array}$ & $\begin{array}{l}95 \% \text { Confidence interval } \\
\text { for average difference in } \\
\text { means or medians }\end{array}$ & p Value \\
\hline \multirow{4}{*}{$\begin{array}{l}\text { Mean initial packed cell volume (SD) } \\
\text { Median peak serum bilirubin concentration } \\
(\mu \mathrm{mol} / \mathrm{l}) \text { (range) } \\
\text { Median volume of concentrated red cells } \\
\text { transfused (ml/kg birth weight) (range) } \ddagger \\
\text { Median supplemental oxygen time (days) } \\
\text { (range) } \int\end{array}$} & $0.564(0.486)$ & $0.509(0.450)$ & 0.023 to 0.087 & $0.0013^{\star}$ \\
\hline & $215(163-309)$ & $254(93-329)$ & -58.0 to 25.0 & NSt \\
\hline & $0(0-58)$ & $23.0(0-120)$ & $-45 \cdot 6$ to $-2 \cdot 2$ & $0.032 \dagger$ \\
\hline & $2(0-7)$ & $5(0-55)$ & -8.0 to 0 & $0.064 \dagger$ \\
\hline
\end{tabular}

*Two sample $t$ test of equality of means of regulated and random groups.

†Mann-Whitney test of equality of medians of regulated and random groups.

$\ddagger$ Numbers of infants receiving concentrated red cells: regulated group six, random group 10 .

§Numbers of infants receiving supplemental oxygen: regulated group 15, random group 18.

TABLE IV-Outcome in ventilated infants

\begin{tabular}{|c|c|c|c|c|}
\hline & $\begin{array}{c}\text { Regulated } \\
(n=13)\end{array}$ & $\begin{array}{c}\text { Random } \\
(n=13)\end{array}$ & $\begin{array}{l}95 \% \text { Confidence interval } \\
\text { for average difference in } \\
\text { means or medians }\end{array}$ & p Value \\
\hline \multicolumn{4}{|l|}{ Mean median arterial-alveolar oxygen } & $0 \cdot 05^{\star}$ \\
\hline \multicolumn{5}{|l|}{ Mean minimum arterial-alveolar oxygen } \\
\hline $\begin{array}{l}\text { tension ratio day } 1(\mathrm{SD}) \\
\text { Mean initial packed cell volume (SD) }\end{array}$ & $\begin{array}{l}0.42(0.24) \\
0.567(0.047)\end{array}$ & $\begin{array}{l}0.22(0.15) \\
0.512(0.048)\end{array}$ & $\begin{array}{l}0.038 \text { to } 0.366 \\
0.016 \text { to } 0.093\end{array}$ & $0.007^{\star}$ \\
\hline \multicolumn{5}{|l|}{ Median peak serum bilirubin concentration } \\
\hline$(\mu \mathrm{mol} / \mathrm{l})$ (range) & $215(163-309)$ & $257(143-319)$ & $-71 \cdot 0$ to $8 \cdot 0$ & NSt \\
\hline & $0.013+$ \\
\hline Median ventilation time (hours) (range) & $22(4-133)$ & $74(9-234)$ & -103.98 to 5.99 & $\mathrm{NS}+$ \\
\hline \multicolumn{5}{|l|}{ Median supplemental oxygen time (days) } \\
\hline
\end{tabular}

«Two sample $t$ test of equality of means of regulated and random groups.

tMann-Whitney test of equality of medians of regulated and random groups.

fNumbers of infants receiving transfusions of concentrated red cells: regulated 5, random 9 .
TABLE $\mathrm{v}-S t e p w i s e$ regression of outcome measures against four possible explanatory factors (birth weight, gestational age, gender, and treatment group)

\begin{tabular}{|c|c|c|}
\hline Outcome & $\begin{array}{l}\text { Explanatory factors } \\
\text { included in final model } \\
\text { (in order of inclusion } \\
\text { into model) }\end{array}$ & \\
\hline $\begin{array}{l}\text { Minimum arterial-alveolar oxygen tension } \\
\text { ratio day } 1\end{array}$ & (1) Treatment group & 15 \\
\hline Initial packed cell volume & $\begin{array}{l}\text { (1) Treatment group } \\
\text { (2) Gestational age }\end{array}$ & \\
\hline $\begin{array}{l}\text { Peak serum bilirubin concentration } \\
\text { Volume of concentrated red cells } \\
\text { transfused } / \mathrm{kg} \text { birth weight }\end{array}$ & $\begin{array}{l}\text { None } \\
\text { (1) Treatment group } \\
\text { (2) Birth weight }\end{array}$ & 5 \\
\hline Duration of supplemental oxygen & $\begin{array}{l}\text { (1) Treatment group } \\
\text { (2) Birth weight }\end{array}$ & 3 \\
\hline
\end{tabular}

${ }^{\star} R^{2}=$ Percentage of variability in outcome measure which can be accounted for by use of linear model with combination of explanatory factors shown.

TABLE VI-Stepwise regression of final outcome measures against seven possible explanatory factors (birth weight, gestational age, gender, treatment group, median arterial-alveolar oxygen tension ratio day 1 , minimum arterial-alveolar oxygen tension ratio day 1 , and initial packed cell volume)

\begin{tabular}{|c|c|}
\hline Outcome & $\begin{array}{l}\text { Explanatory factors included in } \\
\text { final model (in order of inclusion } \\
\text { into model) }\end{array}$ \\
\hline $\begin{array}{l}\text { Peak serum bilirubin } \\
\text { concentration }\end{array}$ & $\begin{array}{l}\text { (1) Minimum arterial-alveolar } \\
\text { oxygen tension ratio day } 1 \\
\text { (2) Gestational age }\end{array}$ \\
\hline $\begin{array}{l}\text { Number of transfusions of } \\
\text { concentrated red cells }\end{array}$ & $\begin{array}{l}\text { (1) Minimum arterial-alveolar } \\
\text { oxygen tension ratio day } 1 \\
\text { (2) Birth weight } \\
\text { (3) Packed cell volume }\end{array}$ \\
\hline $\begin{array}{l}\text { Volume of concentrated red cells } \\
\text { transfused } / \mathrm{kg} \text { birth weight }\end{array}$ & $\begin{array}{l}\text { (1) Packed cell volume } \\
\text { (2) Minimum arterial-alveolar } \\
\text { oxygen tension ratio day } 1 \\
\text { (3) Birth weight }\end{array}$ \\
\hline Duration of ventilation & $\begin{array}{l}\text { (1) Median arterial-alveolar } \\
\text { oxygen tension ratio }\end{array}$ \\
\hline $\begin{array}{l}\text { Duration of supplemental } \\
\text { oxygen }\end{array}$ & $\begin{array}{l}\text { (1) Median arterial-alveolar } \\
\text { oxygen tension ratio } \\
\text { (2) Birth weight } \\
\text { (3) Treatment group }\end{array}$ \\
\hline
\end{tabular}

${ }^{\star} R^{2}=$ Percentage of variability in outcome measure which can be accounted for by use of linear model with combination of explanatory factors shown.

supplemental oxygen dependence was shorter for infants in the regulated group; this reached statistical significance for infants who had been ventilated. Three infants in the random group developed chronic lung disease. Maximum serum bilirubin concentrations recorded were comparable, but one infant in the random group received an exchange transfusion for hyperbilirubinaemia. Hospital discharge age was similar for the two groups. There were no neonatal deaths. One infant in the random group later died unexpectedly at home.

Table V shows results of stepwise multiple linear regression analysis of outcome variables from the ventilated infants. Primary explanatory factors considered were birth weight, gestational age, gender, and treatment group. Treatment group was the most important determinant of the outcome measures considered; these included three "first day" measures which may themselves be useful predictors of subsequent outcome-that is, median and minimum arterial-alveolar oxygen tension ratios and packed cell volume. Stepwise regression was therefore repeated adding these to the set of possible explanatory factors, as shown in table VI. Median arterial-alveolar oxygen tension ratio was more important in predicting respiratory outcome whereas minimum arterialalveolar oxygen tension ratio emerged as the most important predictor for peak serum bilirubin concentration and number of red cell transfusions. First day packed cell volume also emerged as a predictor of transfusion requirements. The effect of treatment group on final outcome measures appears to be mediated largely through its effect on arterial-alveolar 
oxygen tension ratio and to some extent packed cell volume.

\section{Discussion}

Immediate umbilical cord clamping deprives neonates of a significant volume of blood. Although this has no obvious effect on healthy term infants, ${ }^{12} 13$ it may compromise sick and preterm patients. The significant difference in mean packed cell volume between our groups suggests that "regulated" cord clamping enhanced placental transfusion. No infant developed polycythaemia or suffered adverse effects on Apgar scores or temperature. Our inability to standardise the timing of the initial packed cell volume is unfortunate as large changes in plasma volume occur in the first few hours of life. Red cell volume would be a more objective indicator of placental transfusion. ${ }^{14}$ However, the significant difference in packed cell volume between the groups remained when only those samples obtained within the first two hours were compared and also when only those obtained from the third hour onwards were compared.

The immediate haemodynamic effect of interrupting blood flow to the low resistance placental circulation while the umbilical arteries are pulsating is an abrupt rise in systemic arterial pressure with possible deleterious effects. ${ }^{15}$ Hofmeyr et al demonstrated this pressure surge in a term infant and postulated that it contributes to the development of periventricular and intraventricular haemorrhage in preterm infants. They showed a reduction in incidence of such haemorrhages in vaginally delivered infants of less than 35 weeks' gestation with a one minute delay in cord clamping. ${ }^{16}$ In our groups there was no significant difference in the incidence of periventricular and intraventricular haemorrhages. Two cases of posthaemorrhagic ventricular dilatation arose, both in the random group.

The lower transfusion requirements in the regulated group reflected milder illness with less investigational blood loss but may also have related to a greater initial endowment of red cells and their precursors. We have shown that haemoglobin concentrations over $150 \mathrm{~g} / \mathrm{l}$ in the first week tend to protect infants from red cell transfusion. ${ }^{17}$ Clapp et al have shown that cord blood between 25 and 31 weeks' gestation is particularly rich in haemopoietic stem cells. ${ }^{18}$ Thus placental transfusion may be important in constitution of the preterm infant's bone marrow. ${ }^{19}$

Associations have been shown between low packed cell volume or red cell volume, or both, and the respiratory distress syndrome..$^{20-23}$ Although the correlation between packed cell volume and red cell volume in sick patients is not close, ${ }^{14} 24$ the higher packed cell volume in our regulated group probably reflected an enhanced red cell volume. We have shown that red cell volume predicts outcome in preterm infants. ${ }^{25}$

Several studies have suggested that delaying cord clamping protects against the respiratory distress syndrome, ${ }^{78132226}$ although others have failed to confirm $^{2728}$ or even refuted this. ${ }^{29}$ Varying definitions both of respiratory distress and of the terms "early" and "delayed" 1213 confound comparison of these studies.

Although the incidence of the respiratory distress syndrome was similar in our groups there were significant differences in variables reflecting disease severity. Fewer infants in the regulated group required high inspired oxygen concentrations, their median supplemental oxygen dependence time was shorter, and their first day arterial-alveolar oxygen tension ratios were more favourable. The excess of boys in this group makes these differences more remarkable.

Jäykkä described the importance of capillary erection in lung expansion at birth. ${ }^{30}$ Maintaining the fetoplacental circulation intact until respiration is established allows drawing of blood from the placental "reservoir," facilitating pulmonary capillary filling and achieving better lung perfusion. ${ }^{1231}$ We did not time onset of respiration relative to cord clamping but many infants in the regulated group were already crying. This was less likely in infants in the random group, half of whom underwent cord clamping within 10 seconds of delivery. More effective lung perfusion and expansion may have contributed to the more favourable arterial-alveolar oxygen tension ratios in the regulated group.

The arterial-alveolar oxygen tension ratio is a useful prognostic indicator. Tarnow-Mordi et al found the mean arterial-alveolar oxygen tension ratio more closely associated with death than the worst arterialalveolar oxygen tension ratio. ${ }^{32}$ This accords with our finding that median arterial-alveolar oxygen tension ratio predicts respiratory outcome better than the minimum ratio. The former may reflect severity of lung disease, the latter exacerbations of intrapulmonary shunting such as occur with hypovolaemia.

In our study the minimum arterial-alveolar oxygen tension ratio was a predictor of transfusion requirements and of hyperbilirubinaemia. It correlated inversely with peak serum bilirubin concentrations $(r=0.61 ; \mathrm{p}=0.001)$, as did the initial packed cell volume in ventilated infants $(r=0.40 ; \mathrm{p}=0.044)$. Improved splanchnic and hepatic perfusion may result from enhanced blood volume. However, long (one and five minute) delays in cord clamping progressively increase the severity of neonatal jaundice in premature infants. $^{3}$ We found no significant difference in peak recorded serum bilirubin concentrations between the groups.

In summary, a 30 second delay in cord clamping with the infant held $20 \mathrm{~cm}$ below the introitus gives a higher initial packed cell volume and higher arterialalveolar oxygen tension ratios (implying less right to left shunting of deoxygenated blood at cardiac or pulmonary level) on the first day. These independent intermediary outcome variables are both associated with improved final outcome.

This improvement in outcome implies economic as well as clinical benefit. For example, the reduced need for red cell transfusions in the regulated group saved expenditure and patient exposure to transfusion hazards. Had exogenous surfactant been available during the study eight of the 13 ventilated infants in the random group would have qualified for "rescue" treatment by entry criteria for recent multicentre trials $^{33} 34$ compared with only two of the 13 ventilated infants in the regulated group ( $p<0.02 ; \chi^{2}$ test) with obvious financial implications.

Reviews in the early 1980 s called for reactivation of research to establish the optimal positioning of the newborn infant and the optimal time for umbilical cord clamping at preterm deliveries. ${ }^{25}$ Different cord clamping practices at vaginal delivery and at caesarean section still need to be evaluated in terms of effect on blood and red cell volumes and on physiological adaptations to extrauterine life in preterm infants. This should provide a simple, non-invasive means of reducing the costly morbidity associated with preterm birth.

We are grateful to our obstetric colleagues, the midwifery staff, and the paediatric senior house officers and registrars at the Queen Mother's Hospital and also to the staff of the haematology department, Royal Hospital for Sick Children, Glasgow, for their willing cooperation with this study. We are also indebted to Mrs Myra Fergusson for preparing the manuscript.

1 Prendiville $\mathrm{W}$, Elbourne $\mathrm{D}$. Care during the third stage of labour. In: Chalmers I, Enkin M, Keirse MJNC, eds. Effective care in pregnancy and Chalmers I, Enkin M, Keirse MJNC, eds. Effective care in
childbirth. Oxford: Oxford University Press, 1989:1145-69.

2 Peltonen T. Placental transfusion-advantage and disadvantage. Eur f. Pediatr 1981;137:141-6. 
3 Saigal S, O'Neill A, Surainder Y, Chua L, Usher R. Placental transfusion and hyperbilirubinemia in the premature. Pediatrics 1972;49:406-19.

4 Saigal S, Usher RH. Symptomatic neonatal plethora. Biol Neonate 1977:32: $62-72$.

5 Linderkamp O. Placental transfusion: determinants and effects. Clin Perinato 1982;9:559-92.

6 von Engel G. Uber den Zeitpunkt der Abnabelung. Zentralblatt für Gynäkologie 1885;9:721-7.

7 Bound JP, Harvey PW, Bagshaw HB. Prevention of pulmonary syndrome of the newborn. Lancet 1962;i:1200-3.

8 Dunn PM. Caesarean section and the prevention of respiratory distress syndrome of the newborn. In: Bossart H, Cruz JM, Huber A, Prdo'hom LS, Sistek J, eds. Perinatal medicine. 3rd European congress of perinatal medicine, Lausanne 1972. Berne: Huber, 1973:138-45.

9 Gilbert R, Keighley JF. The arterial/alveolar oxygen tension ratio. An index of gas exchange applicable to varying inspired oxygen concentrations. Am Rev Respir Dis 1974;109:142-5.

10 Minitab Inc. Reference manual (release 7). Pennsylvania: Minitab, 1989:6-7.

11 Minitab Inc. Reference manual (release 7). Pennsylvania: Minitab, 1989: 7-15.

12 Buckels LJ, Usher R. Cardiopulmonary effects of placental transfusion. f Pediatr 1965;67:239-47.

13 Moss AJ, Monset-Couchard M. Placental transfusion: early versus late clamping of the umbilical cord. Pediatrics 1967;40:109-26.

14 Jones JG, Holland BM, Hudson IRB, Wardrop CAJ. Total circulating red cells versus haematocrit as the primary descriptor of oxygen transport by the blood. Brf Haematol 1990;76:288-94.

15 Dunn PM. The third stage and fetal adaptation. In: Clinch J, Matthews T, eds. Perinatal medicine. 9th European congress on perinatal medicine, Dublin 1984. Lancaster: MTP Press, 1985:47-54.

16 Hofmeyr GJ, Bolton KD, Bowen DC, Govan JJ. Periventricular/intraventricular haemorrhage and umbilical cord clamping. Findings and hypothesis. $S$ Afr Med f 1988;73:104-6.

17 Holland BM, Wardrop CAJ. Anaemias of the preterm infant. In: Turner TL ed. Perinatal haematological problems. Chichester: Wiley, 1991:121-35.

18 Clapp DW, Baley JE, Gerson SL. Gestational age-dependent changes in circulating hematopoietic stem cells in newborn infants. F Lab Clin Med 1989;113:422-7.

19 Fanaroff AA. In: Klaus M, Fanaroff AA, eds. Yearbook of neonatal and perinatal medicine. St Louis: Mosby Yearbook Publishers, 1990:234-5.

20 Inall JA, Bluhm MM, Kerr MM, Douglas TA, Hope CS, Hutchison JH. Blood volume and haematocrit studies in respiratory distress syndrome of the newborn. Arch Dis Child 1965;40:480-4.
21 Brown EG, Krouskop RW, McDonnell FE, Sweet AY. Blood volume and blood pressure in infants with respiratory distress. I Pediatr 1975;87: 1133-8.

22 Usher RH, Saigal S, O'Neill A, Surainder Y, Chua L. Estimation of red blood cell volume in premature infants with and without respiratory distress syndrome. Biol Neonate 1975;26:241-8.

23 Linderkamp O, Versmold HT, Fendel H, Riegel KP, Betke K. Association of neonatal respiratory distress with birth asphyxia and deficiency of red cell mass in premature infants. Eur $\mathcal{F}$ Pediatr 1978;129:167-73.

24 Faxelius G, Raye J, Gutberlet R, Swanstrom S, Tsiantos A, Dolanski E, et al. Red cell volume measurements and acute blood loss in high-risk newborn infants. F Pediatr 1977;90:273-81.

25 Hudson IRB, Holland BM, Jones JG, Turner TL, Wardrop CAJ. First-day total circulating red cell volume (RCV) predicts outcome in preterm infants (PTI) Pediatr Res 1990;27(4) part 2.209A.

26 Moss AJ, Duffie ER, Fagan LM. Respiratory distress syndrome in the newborn-study on the association of cord clamping and the pathogenesis of distress. ҰAMA 1963;184:48-50.

27 Taylor PM, Bright NH, Birchard EL. Effect of early versus delayed clampin of the umbilical cord on the clinical condition of the newborn infant. Am $\mathcal{F}$ Obstet Gynecol 1963;86:893-8.

28 Frank DJ, Gabriel M. Timing of cord ligation and newborn respirator distress. Am f Obstet Gynecol 1967;97:1142-4.

29 Yao AC, Lind J, Tiisala R, Michelsson K. Placental transfusion in the premature infant with observation on clinical course and outcome. Acta Paediatr Scand 1969;58:561-6.

30 Jäykkä S. Capillary erection and the structural appearance of fetal and neonatal lungs. Acta Paediatrica 1958;47:484-500.

31 Gunther $M$. The transfer of blood between baby and placenta in the minutes after birth. Lancet 1957;i:1277-80.

32 Tarnow-Mordi WO, Ogston S, Wilkinson AR, Reid E, Gregory J, Saeed M et al. Predicting death from initial disease severity in very low birthweight infants: a method for comparing the performance of neonatal units. $B M 9$ 1990;300:1611-4.

33 OSIRIS Collaborative Group. Early versus delayed neonatal administration of a synthetic surfactant-the judgement of OSIRIS. Lancet 1992;340:1363-9. 34 Curosurf 4 Study Group. Protocol. Belfast: Queen's University of Belfast, 1990: appendix 1 .

\title{
Comparison of reduction in microalbuminuria by enalapril and hydrochlorothiazide in normotensive patients with insulin dependent diabetes
}

\author{
Magid Hallab, Yves Gallois, Gilles Chatellier, Vincent Rohmer, Philippe Fressinaud, Michel Marre
}

Service de Médecine $B$ and Laboratoire de Biochimie, Centre Hospitalier Universitaire, 49033 Angers, France $M$ Hallab, research fellow, medical service

Yves Gallois, biochemist Vincent Rohmer, professor of medicine

Philippe Fressinaud, professor of medicine Michel Marre, chief physician, medical service and biochemical laboratory

Service d'Informatique Médicale, Hôpital Broussais 75014 Paris, France

Gilles Chatellier, senior registrar

Correspondence to: Dr M Marre, Service de Médecine B, Centre Hospitalier Universitaire, 49033 Angers Cedex 1, France.

$B M \mathcal{J}$ 1993;306: 175-82

\section{Abstract}

Objective-To compare the effects of sodium depletion and of angiotensin I converting enzyme inhibition on microalbuminuria in insulin dependent diabetes.

Design-Randomised, double blind, double dummy parallel study of normotensive diabetic patients with persistent microalbuminuria (30$300 \mathrm{mg} / 24 \mathrm{~h}$ ) treated with enalapril or hydrochlorothiazide for one year after a three month, single blind placebo period.

Setting-Diabetic clinic in a tertiary referral centre.

Patients-10 diabetic patients with low microalbuminuria (30-99 $\mathrm{mg} / 24 \mathrm{~h}$ ) and 11 with high microalbuminuria (100-300 $\mathrm{mg} / 24 \mathrm{~h}$ ).

Interventions-11 subjects (six with low microalbuminuria, five with high microalbuminuria) were given enalapril $20 \mathrm{mg}$ plus placebo hydrochlorothiazide once daily and 10 (four with low microalbuminuria, six with high microalbuminuria) hydrochlorothiazide $25 \mathrm{mg}$ plus placebo enalapri once daily.

Main outcome measures-Monthly assessment of urinary albumin excretion and mean arterial pressure; plasma active renin and aldosterone concentrations and renal function studies at 0,6 , and 12 months.

Results-Median urinary albumin excretion decreased from 59 (range 37-260) to 38 (14-146) $\mathrm{mg} / 24 \mathrm{~h}$ with enalapril and from 111 (33-282) to 109 (33-262) $\mathrm{mg} / 24 \mathrm{~h}$ with hydrochlorothiazide (analysis of variance, $p=0 \cdot 0436$ ). During the last three months of treatment with enalapril five patients had persistent normoalbuminuria (2-3 times below $30 \mathrm{mg} / 24 \mathrm{~h}$ ), five low microalbuminuria, and one high microalbuminuria; in the hydrochlorothiazide group one had normoalbuminuria, three low microalbuminuria, and six high microalbuminuria $\left(\chi^{2}\right.$ test $\left.=6 \cdot 7 ; p=0 \cdot 03\right)$. Mean arterial pressure did not differ before (98 (SD 7) with enalapril $v 97$ (9) $\mathrm{mm} \mathrm{Hg}$ with hydrochlorothiazide) or during treatment $(88(7)$ with enalapril $v$ 90 (7) $\mathrm{mm} \mathrm{Hg}$ with hydrochlorothiazide (analysis of variance, $p=0.5263$ )). Glomerular filtration rate did not vary. The aldosterone to active renin ratio was decreased by angiotensin I converting enzyme inhibition and increased by sodium depletion, showing treatment efficacy.

Conclusion-Angiotensin I converting enzyme inhibition by enalapril effectively reduces microalbuminuria in normotensive diabetic patients whereas hydrochlorothiazide is not effective. Changes in blood pressure and activity of the reninangiotensin-aldosterone system may contribute to these different effects.

\section{Introduction}

Diabetic nephropathy kills many patients with insulin dependent diabetes. ${ }^{\text {' Data }}$ on experimental animals show that it may be the long term consequence of glomerular haemodynamic abnormalities induced by long term hyperglycaemia. Although systemic blood pressure remains normal, glomerular capillary hydraulic pressure becomes raised because of the imbalance between vasodilatation of the vessels before 